\title{
Tracking the Creative Process of Mikis Theodorakis' Electra: An Approach to Philosophical, Esthetical and Musical Sources of his Opera
}

\author{
Angeliki Kordellou \\ University of Patras, School of Humanities and Social Sciences, Patras, GREECE \\ Department of Theatrical Studies
}

Received: 19 March 2020 - Accepted: 17 May 2020 • Published Online: 28 May 2020

\begin{abstract}
Taking into consideration Mikis Theodorakis' autobiography, personal notes, drafts and sketches, several scientific studies about his musical work and by means of an analytical approach of his score for Electra, it seems that tracking its creative process demands a holistic approach including various musical and extra musical parameters. For this reason the aim of this paper is to present an overview of these parameters such as: (a) aspects of the Pythagorean theory of the Universal Harmony which influenced the artist's worldview and musical creation; (b) the artistic impact of the ancient Greek tragedy and especially of the tragic Chorus on his musical activity; (c) his long term experience in stage music, and particularly music for ancient drama performances; (d) his music for M. Cacoyannis' movie Electra; (e) the use of musical material deriving from previous compositions of Theodorakis; and (f) the reference to musical elements originating from the Greek musical tradition.
\end{abstract}

Keywords: Electra, Mikis Theodorakis, lyrical tragedy, Greek contemporary music, Greek opera.

\section{Introduction}

The tragic fate of Electra has been the source of artistic expression since antiquity. The story of the young princess seeking to avenge the assassination of her father Agamemnon, a death inflicted by his wife, Clytemnestra, and his wife's lover, Aegisthus, inspired painters, sculptors, authors, librettists and composers, theater and film directors. The myth of the Atreides provides topics as revenge, passion, obsession, oppressed sexuality, jealousy, hate, crimes and remains susceptible to updated political, social and psychological analysis and revision. As far as the operatic scene is concerned, even during the twentieth century, Electra still occupies the lyrical scene through Strauss's and Hofmannsthal's Freudian approach of the hero or more recent versions by Greek composers including Mikis Theodorakis (Electra, 1992-3) and George Kouroupos (Pylades, 1992). However, the purpose of this paper is to focus on the "lyrical tragedy" Electra by the Greek composer Mikis Theodorakis (b. 29/07/1925). Theodorakis, mostly renowned for his political activity, composed during a long and prolific musical career numerous song cycles, symphonies, oratorios, scores for stage-, film- and dance music (with most popular the music for Zorbas the Greek) as well as chamber and solo instrument music. Initiated to Greek ancient literature and philosophy since a very young age, he had been composing music for ancient

(C) Authors. Terms and conditions of Creative Commons Attribution 4.0 International (CC BY 4.0) apply. Correspondence: Angeliki Kordellou (PhD), University of Patras, School of Humanities and Social Sciences, Department of Theatrical Studies (member of Specialized Teaching Staff), GREECE. E-mail: akordellou@upatras.gr. 
drama performances since 1960. His stage scores concern many mythical and tragical figures as Phoenician Women, Ajax, Bacchae, Trojan women, Suppliants, Agamemnon, Choeforoi, Eumenides, Hecuba, Antigone, Prometheus bound, Oedipus rex, Medea, Lysistrata. ${ }^{1}$ His first attempts to confront himself with the operatic genre occur in the late 8os with an "opera buffa" (Holst-Warhaft, 2005: 132), entitled Kostas Karyotakis, I Metamorfosis tou Dionysou (1986), commenting and based on the political situation in Greece. His following three operas were based on the ancient tragedies Medea, Electra and Antigone and especially in the case of Medea the composer wrote the libretto himself. Evidently, several questions rise concerning the particular choice (why Electra?), the influence of the Sophoclean model, and ancient tragedy in general, on the creative process and the musical means he applied in order to create this "lyrical tragedy". In order to enlighten the compositional choices, on a first level we will briefly discuss the main points of his philosophical ideas related to the creation of this opera. On a second level, we will focus on the ways the structure, content and essence of the ancient drama and in particular of the tragic chorus are reflected on the libretto. Moreover, we will examine the impact of his compositional experience in music setting of poems, in stage and film music and of the innovative way he perceives the enunciation of ancient tragedy's lyrical parts in this opera. Finally, we will discuss in what ways the composer's view on music's indivisibility is expressed in Electra.

- Tracking the creative process of Mikis Theodorakis' Electra demands a holistic approach.

- The selection of the subject of the opera was based on aspects of the Pythagorean theory of the Universal Harmony.

- The opera's libretto, overall structure and vocal parts were influenced strongly by the Sophoclean Electra.

- Theodorakis' long term experience in music for ancient drama performances played a significant role in the composition of Electra as well.

- The opera Electra expresses the compositional belief in the indivisibility of music.

\section{Universal Law and human archetypes in Electra}

In his notes for the presentation of his opera Electra in Athens in $1998^{2}$ Theodorakis reveals about the choice of the specific topic that "the base was philosophical. I always considered tragedy as the highest level of spiritual conquest of man" (Theodorakis, 1998a). As it occurs in his autobiography (Theodorakis, 1986: 98-9), interviews (Theodorakis \& Gouliamos, 2018: 46), personal notes (digitalized archives of M. Theodorakis - Megaron of Athens), documentaries,

\footnotetext{
${ }^{1}$ 1960: Phoenician Women, directed by A. Minotis, 1961: Ajax, directed by Takis Mouzenidis, 1962: Bacchae, directed by A. Minotis, 1965: Trojan women, directed by Takis Mouzenidis (Festival of Epidaurus), 1966: Lysistrata, directed by M. Volanakis, 1977: Suppliants, directed by Sp. Evangelatos, 1979: Horsemen, directed by G. Lazanis, 1986, 1987, 1988: Agamemnon, Choeforoi, Eumenides, directed by Sp. Evangelatos (all Oresteia in 1990), 1987: Hecuba, directed by A. Solomos (Festival of Epidaurus), 1992: Prometheus bound, directed by Sp. Evangelatos, 1995: Antigone, directed by M. Volanakis, 1996: Oedipus rex, directed N. Haralambous, 2001: Medea, directed by Sp. Evangelatos. See also Panayiotou, 2009.

2 In concertante form on 13 and 15 November 1998, in the Athens Megaron Hall. The opera premiered on 2 May 1995, during the celebration of Luxembourg-Cultural Capital of Europe. Musical direction: Jose Maria Florencio Junior, stag. dir.: Marek Weiss- Grzesiński, scenography: Andrzej Majewski, with the symphonic orchestra, choir, and ballet of the Polish opera. In the role of Electra: Eva Revidi-Ok. Prudnik - W. Nikolajenko, Clytemnestra: L. Tentzeri-Ewa Werka, Orestes: P. Athanasopoulos-Zb. Macias, Chrysothemis: Martha Arapi - J. Cortes, Pedagogue: F. Voutsinos- Bogd. Kurowski, Pylades: St. Beris-Piotr Friebe, Aegisthus: V. Hatzisimos - Sylv.Kostecki. The second performance took place on 13 May 1995, at Poznan, Poland. The third on 30 July and 1 August 1996 at Herodeion Theater, Athens and the fifth presentation on May 1999, at Rialto Theater, Cyprus. See also: http://www.mikistheodorakis.gr/el/music/ergography/opera/?nid=462.
} 
conference papers (Theodorakis, 1998; Theodorakis, 2007: 82-87) and recent studies (see references), a crucial aspect of his vision of the world and his creative trajectory is the concept of the Universal Law that supports the equilibrium between Universal Harmony and Chaos and directs human lives and existence. Theodorakis even as an adolescent believed in the idea of a creative force deriving from the Harmony of the Spheres and his beliefs became stronger and certain when he became familiar with the Pythagorean harmonic theory. The Universal Harmony is reflected accurately, according to the composer, through the coexistence of the Apollonian and Dionysian spirit; the equilibrium between these spirits leads to absolute harmony that can be found in the achievements of the Greek art, from tragedy till sculpture and architecture (Theodorakis, 2007: 85). As he believes, between the Universal Chaos and Harmony exist all kinds of contradictions-opposition of forces such as "time and timelessness, materiality and antimateriality, existence and non-existence, beginning and end, harmony and chaos" (Theodorakis, 2007: 86). These contradictions influence the human fate as well. Through this prism the libretto of Electra constitutes a wonderful example of tragical material, of opposition and conflict. Everybody in this tragedy has good reasons, nevertheless this fact creates opposition. Electra is opposed to her mother and her mother's lover, because they killed her father. Clytemnestra, Electra's mother, was against her husband because he sacrificed her daughter Iphigenia in order to sail for Troy and begin the Trojan War. Clytemnestra is against Electra who accuses and insults her and Aegisthus in public. Electra disputes with her sister Chrysothemis because she does not seek to restore the injustice. Chrysothemis rejects Electra's plan to murder their mother because she is afraid of the consequences of a failed attempt. Orestes, Electra's brother, intends and succeeds to take revenge, opposing himself to his mother and her new husband. However, the two of them, Orestes and Electra, oppose themselves to the Universal Law because they commit matricide and homicide. Evil and good, right and wrong, love and hate and people forced to face those contradictions. Electra, according to the composer "is the chosen one, the one who should respect the natural Laws" (Theodorakis, 1994: 46).

However, another question seems to occur: Why the Sophoclean Electra prevailed over the Euripidian one in the compositional thought? We could assume that as in the case of Hugo von Hofmannsthal's and Strauss' Electra, the Euripidian Electra was considered quite dramatic, subjective and emotionally stressed to allow the formation of a psychological climax. As we may suppose, Theodorakis was familiarized with Euripides' Electra during the composition of the music for M. Cacoyannis' homonym film, despite the reductions and modifications that Cacoyannis inflicted to the original text. However, Theodorakis turns to the Sophoclean model. As Theodorakis says, Electra's personality and status are seductive; "She is so lonely, a beautiful girl, a princess, married to the shadow of her dead father whom she loves so passionately [...] (Wagner, 2000: 443). This description matches the Sophoclean model. On the contrary, Euripides' Electra is not as innocent as the Sophoclean: she is not as helpless - she is married to a poor but noble man who respects her - and, additionally, she becomes the accomplice of Orestes to the murder of her mother. Electra's resentment against her mother reaches unhuman levels. She also accuses Aegisthus for his crimes even after his death. Consequently, her innocence and detriment are not as striking as in the case of Sophocles. The opposition and the contrast between the characters, between justice and crime, by choosing the Sophoclean Electra is magnified.

There are several other elements in this libretto that conform to the theory of the Universal Law. For example, Orestes' friend, Pylades, who is a mute character in the tragedy with no particular role, in Theodorakis' opera is an important character performed by a countertenor. Judging not only by the vocal attributes and symbolism but also by the supportive role of this character in Theodorakis' opera, we should consider Pylades' figure as a form of divine presence, as part of the Universe watching from close people's acts and making sure that natural laws are respected. 
In a deeper level, the law imposes the solution of a moral problem by the murder of the murderers, but this solution - which is also opposed to the law - will not provide the end of a cycle, it will only reveal the beginning of a new one. The tragic fate of Orestes after the matricide will be continued through other tragedies. This happens because the Universe is timeless, the end means beginning. There are no heroes in M. Theodorakis' Electra, there are archetypes related to the history and existence of mankind. People like Electra and Orestes are no different than common people condemned because the Universal Law was violated. The composer does not aim at re-telling the story of Electra: "As long as the spectacle evolves, through the play the archetypes should get alive and function in a way that the spectator gets captivated. I wanted my tragedies [sic] to enter a different ambiance, entirely different, that has no relation with the French, Italian, Mozart's opera. A mystical atmosphere that will captivate you from the moment you seat on the chair, look and listen" (Archimandritis, 2007: 217). More than a faithful representation Theodorakis seeks to create a mystical, ritual, intemporal and universal representation of the myth's essence.

\subsection{Implications of Universal Harmony's theory on Electra's scenery and staging}

In his stage directions Theodorakis (25/6/1994) suggests also that this work could be also seen as religious drama, connecting the earthly and the divine dimension, the human and the superhuman, the earthly and the universal. As he notes, his "Electra should be hieratical" (Archimandritis, 2007). Even the scenery suggested by Theodorakis for the production of the opera at Luxembourg in 1995, supports the idea of anti-spatiality and anti-temporality, the intemporal and repeated contrast between man and natural laws. As Guy Wagner describes in his significant study on Theodorakis, the director "Marek Weiss Grzesiński, adopted an intemporal perspective in the direction of the lyrical tragedy, adhering probably to a stage direction of Theodorakis who judged that Mycenae [the place where the initial story was situated] should be transformed to a magical and supernatural place. Whatsoever the reason was, the stage set-up, reminded of spaceship, space station [...]" (Wagner, 2000: 434-435). We believe that the reason for this scenery is, on one hand, Theodorakis' will to show that the story of Electra, the represented archetypes as well as the actions taken by her and the other characters are part of an eternal cycle, repeating itself independently of specific time or place. This opera's libretto goes far beyond the story of Electra: it is a story about humanity, human fate and reason of existence. On the other hand, people in general are not able to perceive the Universal Harmony: it is a magical place, something incomprehensible and unreachable. The scenery enhances the contrast between the perishable humanity and the unmaterial Universal Law. Mycenae, according to the stage directions of the composer, could be represented as a meteorite, as a spaceship in constant communication with the universal center, the lights should underline the difference among Electra/Chorus and the other characters. The Chorus could be also seen as an incarnation of the Law. However, it would certainly demand a particular discussion -surpassing the limits of this paper - on Electra's staging and scenography in order to fully present the directions of the composer and enlighten fully his intentions. So, remaining within the limits of this presentation, we will proceed with the role of the tragic chorus in this opera and the experience acquired by his collaboration with M. Cacoyannis for his movie on Electra.

\section{The role of the chorus}

The tragic chorus as substantial part of the ancient drama and symbol of a nation or people in general, influenced early the compositions of $\mathrm{M}$. Theodorakis and especially his conception of a new form of musical theater expressed by the Song of the dead brother, a "pop musical tragedy" according to the composer (Giannaris, 1983). The composer remarks: “[...] nowadays we watch the people becoming Chorus, we watch entire nations becoming Chorus. [...]. 


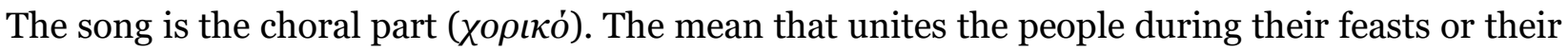
sorrow." (Theodorakis, 1976: 51). In the Song of the dead brother, the composer uses the choral dance in combination with the collective song in order to ensure the passage from the personal to the general, "from the realistic action to the lyrical expression", following the example of the ancient drama (Theodorakis, 1976: 78). Consequently, the role of the chorus in his opera - both symbolic and dramatic - could not be sporadic or ornamental, despite the necessary changes imposed to the ancient text during the formation of the libretto.

Spiros Evangelatos, the librettist, reduced the original text, respecting however the Sophoclean verses. Consequently, the structure and content of the opera was strongly influenced by the tragedy. Theodorakis' Electra is divided in two acts with nine and seven scenes respectfully. The monologues of the initial text are shortened, the dialogical parts are favored -they express in an immediate and vivid way the conflicts between the characters- and the choral parts very abundant, at least for a contemporary opera. More than fifteen choral interventions in an opera of two and half hours in the 2006/7 shortened and revised edition (Schott, Theodorakis: Electra. Revised and shortened version of the composer, 2010) - the original edition (1992-3) included more parts - remind us well of the role of the ancient tragic Chorus. It should be noticed that, beyond the references to the tragedy, the formation of the choir reflects Theodorakis' democratic ideas. The fact that the chorus expresses the people, the public opinion and will - not surprisingly by a man with the political and social activity of Mikis Theodorakis - had a great impact on the choral parts of his Electra. Instead of a group of women, as in the case of both tragedies mentioned above, the composer adds a group of aged men and completes his four-voice choir. The choral parts in Electra are meant to be "popular": they intend to show the active participation of the people to political and social matters. They do not serve neither decorative nor intermission's purposes and they do not suppress the action. On the other hand, this democratic perspective leads Theodorakis to opt for a simple, clear and comprehensible choral writing. Theodorakis perceives the chorus as "principal character, [fact]...that is valid for his stage presence as well [...]. For this reason, at a large part, the chorus remains monophonic" (Theodorakis, 1998b: 2). Electra's chorus, is not a group of followers; They may be sympathetic - they mourn for Electra's fate, the fake death of Orestes, even the death of Clytemnestra and Aegisthus - but they do not applaud on every decision Electra makes. They recognize and accept the Universal Law as well as Electra's and Orestes' dilemma. Their sympathy is musically symbolized and communicated through the reprocessing of musical material used previously in Electra's vocal parts.

\section{Composing for M. Cacoyannis' Electra}

As mentioned above, the approach of Electra's fate by the composer - on an artistic level - comes firstly with the production of the homonym film directed by Michalis Cacoyannis (starting Irene Papas). Cacoyannis based his scenario on the Euripidian version of Electra's story imposing several modifications and cuts while Theodorakis have been composing in Paris, between 1961-2, the music for the movie, for an ensemble including voice, piccolo, clarinet, baglamas (small bouzouki), santouri (Greek form of cimbalom), contrabass and percussion (the compositional drafts include more instruments). It was not his first attempt in the field of film music, but the first one on a cinematized tragedy considered afterwards quite successful (nominated for Oscar). The absence of speech in several parts of the film allows the music to act in a dramatic manner keeping pace with the action and (when necessary) the speech. "Cacoyannis' intention in Electra was to transfer the emotional content of the poetic lines to the movements and portrayals of the tragic characters themselves; the emotional is expressed visually while the poetical line is cut and distributed in the dialogue [...]. The need for music in many scenes in Electra is so great that in its absence the scenes would have been eliminated: the music is so identified with the drama that it equals action. The result is a dramatic unity, the music reflecting the harsh, dry landscape - which is an integral part of the expanded ancient stage-and serving as 
counterpoint to the action and emotion" (Giannaris, 1983). The role of the music in Cacoyannis' Electra goes far beyond the creation of a musical background or ambience as film music usually functions in other productions. For this reason, as we will demonstrate in a more analytical way in section 6 of this paper, many of the musical themes, melodic and rhythmic motifs, even instrumental choices and timbres reoccur in his operatic Electra.

\section{Composing music for ancient drama performances}

Theodorakis was greatly inspired by ancient drama since at least the 40 os when he composed the symphonic Prometheus Bound (1946), without however faithfully following the Aeschylian text. Later, he confronts himself again with the problems of musical conception of tragedies (and in particular of the choral parts) through the composition of the orchestral Oedipus Tyrannos (or Oedipus Rex, Ode pour orchestre à cordes, 1958) and his ballet Antigone (1959). During the first half of the twentieth century, the lyrical parts of the tragedies - choral and solo, the so-called monodies ( $\mu$ ov $\omega \delta i \varepsilon \varsigma$ ) - were disregarded and largely replaced by speech or collective rhythmic recitation (in the case of the choral parts) with a few exceptions as the performances directed by Eva Palmer-Sikelianou during the Delphi feasts $(1927,1930)$ or the stage music of Dimitris Mitropoulos, Menelaos Pallantios and Manos Hatzidakis for the productions of Hippolytus (1936), Hecuba (1955) and Medea (1956) respectively. In 1959, Theodorakis underlines the problem of the musical accompaniment in the new performances of Greek tragedy (Theodorakis, 1959) expressing the opinion that the music should be united "in a material way" with the cries of the chorus or the hero, or "dynamically" with the tension of the tragic moment. A year later, the collaboration of Theodorakis with Alexis Minotis, the famous director and actor of the Greek National Theater for the production of The Phoenician Women, brought a new dimension to the usual performances by adopting a singing enunciation (in alternance with the rhythmic) of the text performed by the Chorus. For the composer, figuring already among the Greek composers inclined to set to music contemporary Greek savant poems, the music for the ancient drama should be deriving from the text itself. On the occasion of the stage music for the Phoenician women he remarks that: "it is not the composer's task to support the recitation neither to create an atmosphere, but to 'listen' to this mystical music arising from the verses themselves" (Zahou, 2009: 72). Since the ancient Greek drama was an amalgam of poetry, music and dance, and the musical meters coincided to the poetical ones, the verses of a Greek tragedy demanding of musical setting could be more than the half, and, especially in the case of the Phoenician women, -according to Theodorakis- could reach approximately the 80\% of the play (Zahou, 2009: 94). A new form of opera was then proposed to Minotis by M. Theodorakis: "we had discussed with Minotis and Paxinou the creation of a different kind of opera, not savant according to a European concept, but by simpler musical means, since there would be actors singing. The concept, however, would be the same [as in ancient drama]. I should use a large amount of symphonic sound, exactly as I did in Axion Esti, but not in such a large scale, that would disorient the people. [...] And that's what I did by inserting in my operas the symphonic sound - combined however with the return to tonality, and to the preponderance of melody" (Archimandritis, 2007: 215-6). Unhopefully, this suggestion was postponed and finally condemned by the political situation. However, Theodorakis' attempts, originating from the vision of a lyrically enunciated tragedy, lead him not only to aspire to a new musico-theatrical form, but also to preserve the unity of the triptych speechsong-drama in the vocal parts of his operas. "In all my three operas, my major concern was to convert the text to melisma-song [...]. I did not consider the speech detached-isolated, on the contrary I was integrating the speech in a general context which was affecting decisively the final formation of the melisma-song. To speak with terms of occidental music, my recitativo [sic] did not have the characteristics neither of the simple musical recitation nor of the aria" (Theodorakis, 1998a). 
The creation of a musico-theatrical form able to provide the catharsis, adapting the symphonic sound but giving also preponderance to the melody, was a reason that dictated Theodorakis' return to tonality and melodic lyricism in order to compose his operas (Archimandritis, 2007: 216). The harmonic aspect is influenced too by this tragedy-centered compositional view as far as the Chorus accompaniment is concerned; the thin orchestral sound (sometimes rudimentary) allows the choral parts to be intelligible. On the contrary, during the vocal ensembles, the harmonic texture becomes more complex because, according to the composer, "all opinions must be heard" and "in order to understand the "logic" of one the essence of the other should be understood as well" (Theodorakis, 1998b). As the logic of one does not exclude the opinion of the others, the orchestra acquires as well a dramatic role. Consequently, simultaneous but distinct harmonic layers may evolve in parallel with vocal ensembles or solo sections.

\section{The indivisibility of music}

Mikis Theodorakis designed a map of his compositions clearly demonstrating the indivisibility of his musical poetic, the organic connection and harmony among the various stages and achievements of his creative activity. We should note that the concept of indivisibility for the composer applies to music in general and not only to his compositions (Folkerts, 2015: 224). A far as his repertoire is concerned in particular, every composition is regarded as part of a whole that does not exclude forms and genres, past and present, traditional elements and new possibilities of expression. Electra is not an exception. As it occurs in his map, the compositional process leading to the operatic Electra is connected to the homonym film (1962) and ballet (1979), the ballet Antigone, 1958/1959, the cycle of songs Faces of the sun (1986), a vocal piece based on a poem of Kostis Palamas entitled For a dead woman (1992), a cycle of songs on poems of Paul Eluard and shows a more distanced relation with the Ballades (1973) and a more recent Small rhapsody for piano. The strongest attachment, and apparently the most conscious one, is obviously to the film music as it will be shown. In this case, the influence of the traditional music is evident not only in the use of melodic motifs and rhythms, but also in the timbre and the orchestration. The sound of conventional European instruments is combined with the traditional one provided by Greek popular instruments such as the santouri and baglamas partly in an attempt to approach the sound of an ancient Greek lyre, aulos or tympanon (percussion). These elements reveal on one hand the relation between the music of the film and the experience of Theodorakis through ancient drama's music setting. It should be noted that byzantine chant and traditional music were considered as the natural continuation, the natural successors of ancient Greek music or the means to achieve a realistic archaistic sound fitting to ancient drama representations. On the other hand, Theodorakis is renowned for his innovative idea to reconcile the popular instruments to the symphonic, an idea realized already - despite all reactions - in his Epitaph (1962). However, more than $50 \%$ of this film music was to be transferred in another context, the one of the opera Electra, and this insertion was realized in a harmonic and functional way in relation with the newly composed material. For example, the piccolo's melodic line, heard while the sun rises on the day of the crisis in the film (Cacoyannis' Electra, draft, no 102), occurs (in a variated form) in the melodic line of Electra's entrance; It gives the impression of a summoning to the gods. The same melodic line was preceding Electra's entrance, probably because she is connected to the universal light and justice, in the 1998 production, 3 but was eliminated in the newest revision (Electra's score, Schott, 2010). In that later, it sounds at the beginning of the second act (scene 1) where justice will be accorded and the light of the Universal Harmony will rise. Another example is provided by the initial musical theme of the movie (Figure 1), reminding of the second chromatic

${ }^{3} 3$ CDs, conducted by Mikis Theodorakis, with the St. Petersburg State Academic Capella Orchestra \& Choir, intuition Classics (2000). 
mode of byzantine (church) chant or the kartzigar makam. The theme is firstly enunciated during the assassination of Agamemnon in the movie, consequently, is combined with revenge. Its ascending motifs lie beneath several instrumental parts of the opera e.g. after Electra's description of Agamemnon's murder to the chorus (fourth scene, bars 72-4). Its conclusive motif will reappear in a variated form (bar 109) at the same scene, by the horns, delivering a "suspicion" of vengeance.

The integration of material from the film's suite seems conscious and dramatically connected as it may be deducted by the "transferred" - from the movie to the opera - symbolisms and connotations. As mentioned above, this suite was destined also to an Electra, written by Euripides and reviewed by Cacoyannis, but the initial story has no great differences in comparison to the Sophoclean. There are however 'involuntary' intertextuality in Theodorakis' Electra. As the composer remarks: "there are themes which I did not wish to leave in the dark and which returned by themselves. When I compose a melodic line, at a certain point in time I am unconsciously led to a theme which is not new, but suddenly there. Thus, there are themes based on works from 1942 in my newest pieces" (Wagner, 2000: 441). An example can be provided from the eighth scene of the first act (bars 265-319). The theme comes from a song of the Faces of the sun cycle entitled

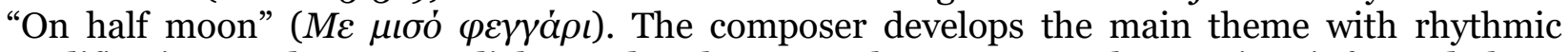
modifications and creates a dialogue-duet between Clytemnestra, who was just informed about Orestes' (fake) death, and Orestes' Pedagogue, who pretends to be a friend from a friendly state, Fokida.

Theodorakis in his compositions often combines occidental and Greek motifs, modes, scales, rhythms, instruments. As we have noticed, the Greek musical elements borrowed from the movie suite were incorporated in the symphonic language of the lyrical tragedy. The dramatic context, after all, calls for diversified textures which could underline the continuous opposition and conflicts between the characters and the psychological alternance from despair to joy, from peacefulness to murder. A motif from the monophonic byzantine hymn of the vespers entitled Gentle light ( $\Phi \omega \varsigma$ I $\lambda \alpha \rho o ́ v)$ in the second byzantine mode with harmonic elaboration, initiates Electra's prayer (act 1, scene 5, bars 422-437: I believe, yes, I believe...). The peace of the scene is followed by the barbaric, military sound of the following musical theme: The chorus is prophesying the return of Justice (beginning of scene 6, act 1).

Although dramatic contrast and rupture demand for diversified musical textures and colors between the scenes of the opera, the composer uses musical themes and motifs as leitmotifs or repeats them in order to underline what must be done, the real purpose of the action. For example, the musical theme of Chrysothemis (act 1, scene 5, bars 220-229) - closely related to a motif from the movie (when Electra promises to help Orestes take revenge using an axe) enunciates in the opera Clytemnestra's dream preconizing her death (lento, espressivo). It is transformed in a furious attack by Electra (allegro vivace) trying to convince Chrysothemis to reject her mother's offerings to Agamemnon's grave and to offer hers instead. The hope of Orestes' return appeases her grief and after a short prayer, Chrysothemis is consenting to her sister's will with a reminiscent form of the same theme (from bar 489). The theme returns through Electra's desperate mourning for her brother. According to the composer's notes in the revised edition (see score, 2010): "in the finale of the first act, Electra sees the moment of vengeance: the death of Aegisthus. When at the end of the work the scene will be repeated, Electra must give the impression that the facts taking place in front of her eyes were already experienced. That is the reason why the finale of the first act and the end of the work coincide." In a connective manner for the drama as well, the melody of the piccolo mentioned above, reappears e.g. when the name of Orestes is referred in the libretto. The chorus as well retakes the melodic lines of Electra in order to show his consensus. If, at the beginning, everything seems to scatter in different directions, the notion of a thematic nucleus, however, is to be found. This happens probably in analogy with the center of the Universe from where all kind of incongruous forces emerge without nevertheless destroying its balance. 


\section{Conclusion}

Reaching at this point of our approach on Theodorakis' Electra, we may conclude that in order to track the creative process leading to its fulfillment a holistic approach is necessary. However, the research should not only focus on the composer's musical creation, as Guy Wagner suggested in his study, but also on several other aspects of apparently non-compositional importance (see Figure 3). As it was shown, his philosophical thesis about the Universal Law and the meaning of the human life played a particular role in the selection of the operas' theme, the creation of the libretto, the scenery-staging and the macrostructure of the work. In addition, his experience and artistic visions connected to the music for ancient drama performances, his concern for optimizing the lyrical, dramatical and political role of the tragic chorus, as well as his activity in setting the tragic verses into music lead to a series of compositional choices defining the esthetic result of his opera. From a musical point of view, Electra expresses the compositional belief in the indivisibility of Music through the combination of heterogeneous, new or old, personal or traditional musical material, structures, timbres and forms without however compromising the coherence of the opera.

\section{Acknowledgements}

This research did not receive any specific grant from funding agencies in the public commercial, or not-for-profit sectors.

The author declares no competing interests.

\section{References}

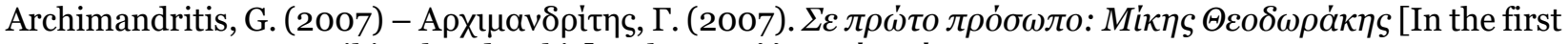

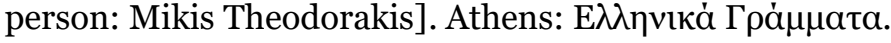

Folkerts, G. (2015). Mikis Theodorakis: Seine musikalische Poetik. Neumünster: Bockel.

Giannaris, G. (1983). Music and theater. Mikis Theodorakis. Athens: Efstathiadis Group.

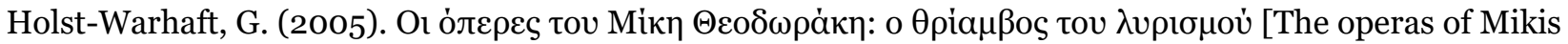

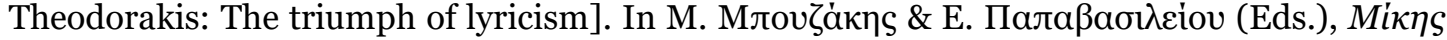

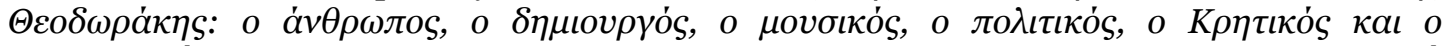

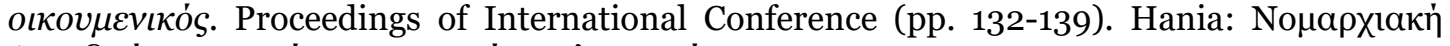

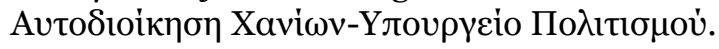

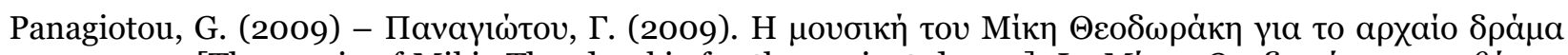

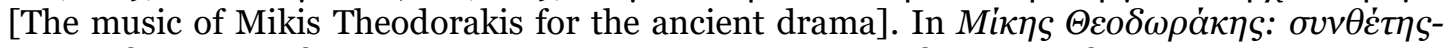

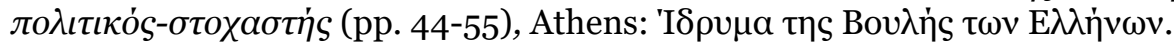

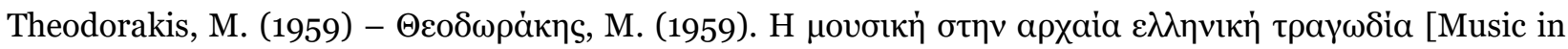
ancient Greek tragedy]. Retrieved 18 April 2020, from www.digma.mmb.org.gr/.

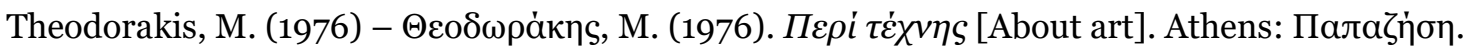

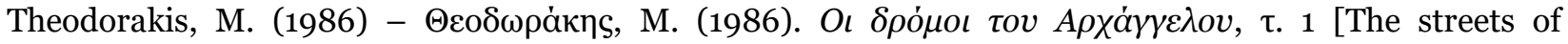

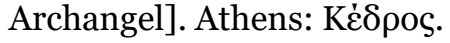

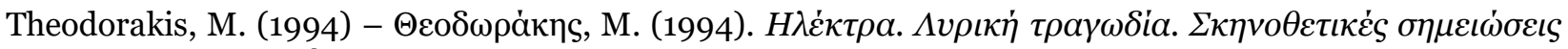
(KoptvӨia, 25/o6/1994) [Electra. Lyrical tragedy. Stage direction notes]. Retrieved 18 April 2020, from www.digma.mmb.org.gr/. 
A. Kordellou - Tracking the Creative Process of Mikis Theodorakis' Electra: An Approach...

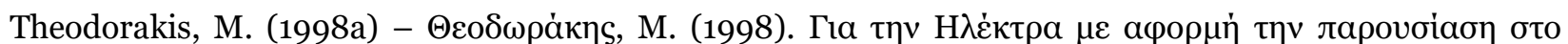

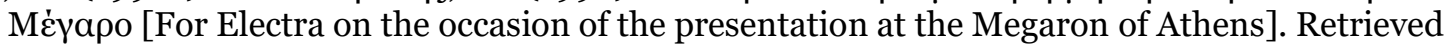
18 April 2020, from www.digma.mmb.org.gr/.

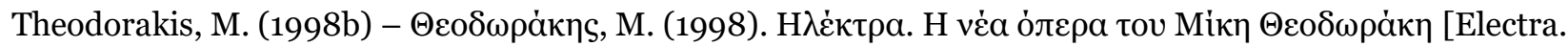
The new opera by Mikis Theodorakis]. Retrieved 18 April 2020, from www.digma.mmb.org.gr/.

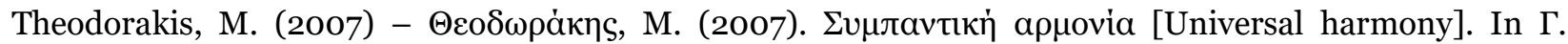

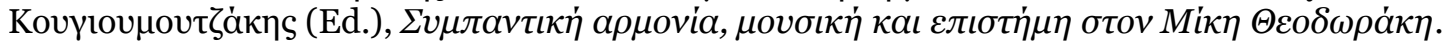

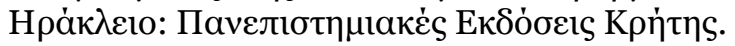

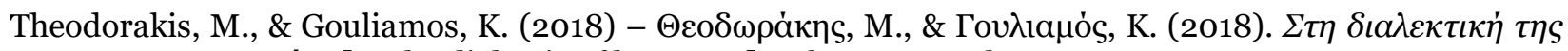
a $\rho$ ovias [In the dialectic of harmony]. Athens: Gutenberg.

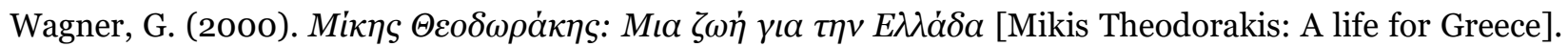

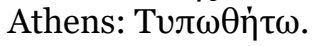

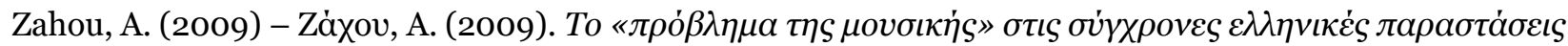

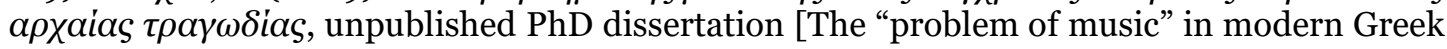

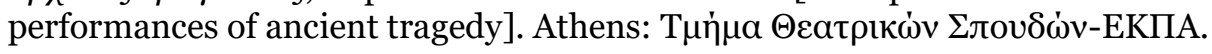


Appendix

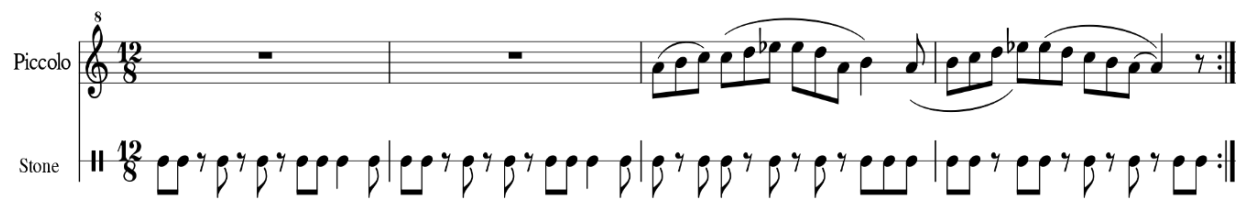

Figure 1. M. Theodorakis music for Cacoyannis' Electra (only piccolo and stone)

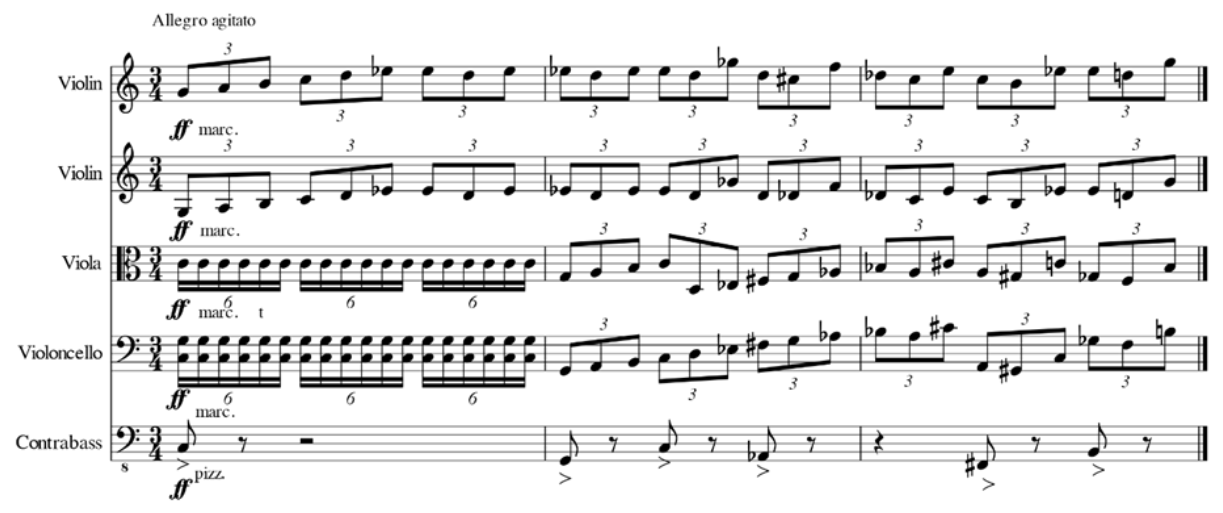

Figure 2. Electra: M. Theodorakis, Act 1, scene 4, bars 72-4 (strings only)

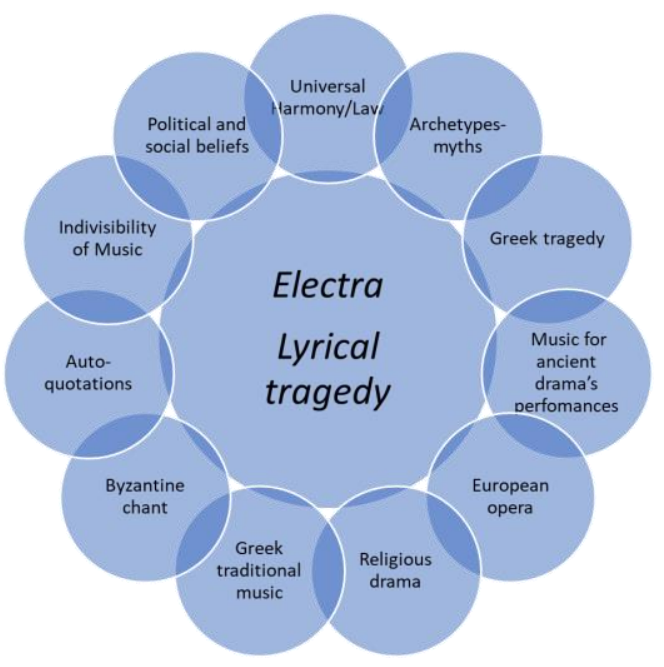

Figure 3. Musical and extra-musical axes forming the creative process of Theodorakis' Electra 
A. Kordellou - Tracking the Creative Process of Mikis Theodorakis' Electra: An Approach...

C O A $\mathrm{s}$ 